\title{
Creative and productive workplaces: a review
}

Article

Accepted Version

Clements-Croome, D. (2015) Creative and productive workplaces: a review. Intelligent Buildings International, 7 (4). pp. 164-183. ISSN 1750-8975 doi: https://doi.org/10.1080/17508975.2015.1019698 Available at https://centaur.reading.ac.uk/67748/

It is advisable to refer to the publisher's version if you intend to cite from the work. See Guidance on citing.

Published version at: http://dx.doi.org/10.1080/17508975.2015.1019698

To link to this article DOI: http://dx.doi.org/10.1080/17508975.2015.1019698

Publisher: Earthscan

All outputs in CentAUR are protected by Intellectual Property Rights law, including copyright law. Copyright and IPR is retained by the creators or other copyright holders. Terms and conditions for use of this material are defined in the End User Agreement.

\section{www.reading.ac.uk/centaur}

\section{CentAUR}

Central Archive at the University of Reading

Reading's research outputs online 


\title{
Creative and productive workplaces: a review
}

\author{
Derek Clements-Croome*
}

School of Construction Management and Engineering, University of Reading, Reading, UK

\begin{abstract}
The built environment affects our well-being and this in turn influences our effectiveness in the workplace. Poor environments contribute to absenteeism and to people not working as well as they might. This is an enormous cost to the nation. High-quality environmental design is an investment, as occupants are healthier, staff-retention rates are higher, productivity is higher and sustainability ideals are more likely to be met. Workplaces reflect the culture of companies and are places that are not just functional and convenient but give the occupant a wholesome experience in terms of body and spirit.
\end{abstract}

Keywords: health; productivity; sustainability; well-being; workplace

*Email: d.j.clements-croome@reading.ac.uk

\section{Introduction}

Architecture is more than the art of constructing individual buildings. It is also the creation of environment. Buildings do not exist in isolation. They not only impose their character on their surroundings but also have an incalculable effect on the lives of human beings who inhabit them.

(Conti 1978)

Over the past 20 years, it has been empirically assessed that most building environments have a direct effect on the occupants' personal well-being and performance; however, it is only through more recent studies that a clearer understanding of the occupied environment has been discovered. Bakó-Biró et al. $(2008,2012)$ have shown that primary school children's concentration is affected by $\mathrm{CO}_{2}$ levels between 1000 and 5000 ppm, and hence the design for 'effective' fresh-air ventilation is vital. Effective means the fresh air reaches the breathing zone and vital because there is an effect on learning performance. Satish et al. $(2011,2012)$ describe research evidence showing that $\mathrm{CO}_{2}$ affects decision-making even at levels as low as 600 ppm, which is below the normally accepted level of $1000 \mathrm{ppm}$. This raises the question as to the validity of the codes and standards we have used for years without question concerning noise, light and temperature. In the UK, the Building Schools Exhibition and Conference (CIBSE 1999) asked head teachers if they felt modern buildings affect learning. Around $78 \%$ said that they felt there was a clear link between the quality of school design and levels of pupil attainment. Williams (2006) reported a similar conclusion for 12 primary schools, which he assessed using the building quality assessment (BQA) method and compared the BQA scores with 
examination results. There was a clear correlation between building quality and students' performance. Bernstein and Russo (2013) also found that student performance was better in green schools. Other measures of building quality include the design quality indicator (Construction Industry Council 2002) and the many rating tools available such as BREEAM, leadership in energy and environmental design (LEED), Green Star, Comprehensive Assessment System for Built Environment Efficiency, Sustainable Built Environment Tool and others.

Koegelenberg (2014) questions if green buildings increase employee wellness. She quotes the work of Singh et al. (2010) at Michigan State University which compared human performance in a traditional building with that in a green building and showed that there was an improvement in health and a consequent reduction in absenteeism. Miller et al. (2009) surveyed over 500 LEED and Energy Star-rated buildings, and proved their hypothesis that healthy buildings reduce the number of sick days, increase productivity and make it easier to recruit and retain staff. More evidence supporting this argument shows that sustainable buildings decrease business costs and energy costs and increase the value of the built asset, as the increasing societal awareness of green buildings deepens the demand for sustainable buildings (Clements-Croome 2004a, 2004b; Newell 2009; Thompson and Jonas 2008), and legislation is forcing the pace. The question now is 'Can one afford not to be sustainable?' Bernstein and Russo (Personal communication, 2010) wrote that US environmentally labelled buildings rent for 2-3\% more and have higher staff-retention rates and decreased operating costs, and in 2008 the value of these buildings increased by 10\%. Newell (2009) quoted evidence showing that LEED-rated buildings cost $6 \%$ more to build, have staff-retention rates over $4 \%$ higher, command $2-6 \%$ higher rents and save $10-50 \%$ in energy consumption. Integrated design and management processes may reduce this extra build cost of about $6 \%$ to the point where there is no extra cost. In South Africa, Volume 6 of the Green Building Handbook 2014 edited by L. Van Wyk focuses on improving building design with respect to human health.

Eley Associates (2001) found that healthy buildings lead to better work performance, and this is supported by other works such as that by Bell et al. (2003), Clements-Croome (2006, 2013), and Mendell et al. (2002).

There seems to be a virtuous circle linking health, sustainability and environmental quality. Better building performance is likely to lead to better human performance. Of course, other factors are important, such as job satisfaction, the social ambience in the workplace and personal issues. Here, 'health' relates to both mind and body. Our surroundings can influence 
our moods, our concentration, and enhance or detract from our basic motivation to work. Some people are more sensitive to their surroundings than others, but we should aim to satisfy the most sensitive people rather than design for average preferences, which neglect individual differences. van der Voordt (2003) believes that employees who have interesting and beautiful environments towork in tend to be more productive.

Surveys by Jones Lang LaSalle (2013) put health and well-being ahead of energy, transport, waste, pollution and water in a priority list of sustainability factors. The top five most mentioned sustainability measures were daylight, air quality, energy consumption, flexible layout and good transport access. Furthermore, the four most important reasons stated for becoming sustainable were higher productivity, image, smaller ecological footprint and lower health-related absenteeism.

The main conclusions from the Gensler (2013) Workplace Survey of some 2000 knowledge office workers in USA were:

O US workers struggle to work effectively.

- Need to balance focus and collaborative working to afford higher job satisfaction and performance.

- Personal choice drives performance and innovation and improves the workplace experience.

- Think holistically about the needs for focus, collaboration, learning and social ambience, leading to variety of spaces offering anywhere working policy.

- Drivers of focus are functionality, satisfactory noise levels and design look and feel.

- Drivers of balance are meeting space, circulation and support space, in-office amenities.

- Drivers of choice are variety of spaces, tools and policy to let employees match their space to their needs.

- Less space per person is a false economy as work effectiveness decreases.

- Offices provide a 'home' for 'work families'.

- Building can give a sense of pride to employees.

Gensler's use their Workplace Performance Index derived from a web-based measurement and analysis pre- and post-occupancy evaluation (POE) tool for work environments to help clients 
understand specifically what comprises space effectiveness so that design solutions can be tailored accordingly.

Peer-reviewed research and case studies used in the World Green Building Council Report (WGBC 2013) establish the case for green building show that:

- Green buildings do not necessarily cost more and appeal to tenants because they command higher rents and sale prices.

- Operating costs are lower because of reduced energy and water use plus reduced maintenance.

- Better environments affect employees and lead to higher staff-retention rates.

- Workplace illnesses and hence absenteeism are reduced - whilst well-being is higher than in conventionally designed offices where high-quality environments have not always been a priority.

Too often buildings are seen as costly static containers rather than as investments which, if they are healthy and sustainable, can add value. Boyden (1971) distinguished between needs for survival and those for well-being. Human beings have physiological, psychological and social needs. Heerwagen (1998) pinpointed the well-being needs relevant to building design as

- social milieu,

- freedom for solitary or group working,

○ opportunities to develop self-expression,

- an interesting visual scene,

- acceptable acoustic conditions,

- contrast and random changes for the senses to react to,

o opportunities to exercise or switch over from work to other stimulating activities and

$\circ$ the need for clean fresh air.

Stools (1992) states that physical, emotional and social conditions together are a requisite for good health.

In practice, investors, developers and clients often agree that sustainable healthy buildings are desirable but want quantified economic evidence to persuade them to finance such projects. Social awareness is changing about the need for sustainable green buildings. The US Green 
Building Council published a report in 2003 entitled Making the Business Case for High Performance Green Buildings and some of the conclusions included the following.

- Higher capital costs are recoverable in a comparatively short time.

- Integrated design lowers operating costs.

- Better buildings equate to better employee productivity.

- New appropriate technologies may enhance health and well-being.

- Healthier buildings can reduce liability.

- Tenants' costs can be significantly reduced.

- Property value will increase.

- Communities will notice your efforts.

- Using best practices yields more predictable results, but remember that occupancy behav- iour affects the performance.

- Respect the landscape and open space near the building.

\section{Environmental factors}

How people feel about their physical surroundings, can impact on not just mental health and wellbeing, but also physical disease. (Scottish Government 2006)

In researching the impacts of the environment on people, it is common to read that environmental factors can act as stressors. Odours, sound, air quality, temperature and light can affect humans physiologically, affectively (emotionally) and psychosomatically (mentally). The reactions can lead to positive or negative stress. Stressors can cause increased heart rate, vomiting, shallow breathing and muscle tension. They can affect brain rhythms and alter the alpha, beta and theta patterns, which are correlated with mood and affect. Affective states affect judgment, productivity, interpersonal relations, self-image, morale and aggression. So, one can see the chain of possible physiological and psychological reactions that may occur when exposed to the environment. There are clues here also as to how physiological measures may aid our understanding of human reaction to the environment.

We experience life through our senses, and intelligent buildings should provide a multisensory experience. In general, POE data show that people are very positive about spaces that are airy, fresh, have natural light, and views out onto, preferably, natural landscapes (Clements-Croome 2006; Strelitz 2008). If an environment is to be conducive to health and 
well-being, it should display the following characteristics:

- A fresh thermal environment.

- Ventilation rates sufficient to provide fresh air with good distribution and acceptable levels of $\mathrm{CO} 2$.

- Good natural lighting.

- Acceptable acoustic climate.

○ No lighting glare.

- Spatial settings to suit various types of working.

- Ergonomic workplaces that have been designed to minimize musculoskeletal disorders.

- The landscaped surroundings should be properly considered as part of the design.

- Minimum pollution from external sources, including noise.

Personal control of these factors, wherever possible, is important. Central control for items such as security is fine, but people prefer to have some degree of control over their immediate physical environment (Ulrich 1991).

Fresh air, warmth or cold, daylight, sound, space and ergonomics are all important in designing the workplace. However, in the depths of winter or at the height of summer, the temperature tends to be the issue that workers comment about most frequently. However, the current sustain- ability agenda features energy as a highly important factor, and this is closely related to the temperature at which we maintain our buildings. A UK survey carried out by Office Angels and the Union of Shop, Distributive and Allied Workers (USDAW 2006) drew the following conclusions:

- Heat exhaustion begins at about $25^{\circ} \mathrm{C}$.

- The maximum air temperature recommended by the World Health Organization (WHO) for workers' comfort (but note that in the UK there is no legislation covering maximum allowed temperatures) is $24^{\circ} \mathrm{C}$.

- The minimum temperature recommended by the UK Workplace (Health, Safety and Welfare) Regulations $1992\left(13^{\circ} \mathrm{C}\right.$ for strenuous physical work) is $16^{\circ} \mathrm{C}$.

○ In all, $78 \%$ of workers say that their working environment reduces their creativity and ability to get the job done. 
- In all, $15 \%$ of workers have arguments over how hot or how cold the temperature should be.

- In all, $81 \%$ of workers find it difficult to concentrate if the office temperature is higher than the norm.

- In all, $62 \%$ of workers state that, when they are too hot, they take up to $25 \%$ longer than usual to complete a task.

The well-established work on adaptive thermal comfort done by Nicol, Humphreys, and Roaf (2012) shows that the internal temperature should be chosen according to the monthly mean temperature. Furthermore, the study by Oh (2005) comparing conditions in Malaysian offices with those in the UK showed that people do adapt to temperature, but not to air quality. Olfactory reactions to pollutants are similar across countries.

Indoor air quality is as important as temperature (Clements-Croome 2008; Fanger 2002). Fresh air is, like water, vital to life. A danger with sealing buildings to reduce their energy consumption is that there will be insufficient fresh air, so it is important to build in a controlled air supply such as trickle ventilators or properly located windows that can be opened a little or a lot depending on the seasonal weather.

The link between odour and scents and work performance is less well understood, but Fisk (1999) concludes that the literature provides substantial evidence that some odours can affect some aspects of cognitive performance. He refers to the work by Baron (1990), Dumber, Warm, and Parasuraman (1995), Knasko (1993), Ludvigson and Rottman (1989) and Rotton (1983). Aroma essences have been used in the air-conditioning systems in the Tokyo office building of the Kajima Corporation (see Takenoya in Clements-Croome 2006).

'Freshness' is an underused term in design, yet occupants often talk of the need for a fresh environment (Chappells 2010). Many factors can contribute, such as colour, spatiality and, more often, air quality. Air quality is a combination of the $\mathrm{CO}_{2}$ level, temperature, relative humidity and air movement. Chrenko (1974) researched thermal freshness using a sevenpoint scale, where subjects rated the freshness from 'much too stuffy' to 'much too fresh', and found that freshness was dependent on air velocity and temperature. Clements-Croome (2008) based on the UK office surveys proposed a relationship between fresh air requirements and air temperature for a relative humidity range of $40-60 \%$ and average air velocities of 0.2 $\mathrm{m} / \mathrm{s}$. For a 'moderately' fresh environment, as judged by a sample of 223 UK office workers, a fresh-air rate of $2.2 \mathrm{l} / \mathrm{s}$ per person at $20^{\circ} \mathrm{C}, 6.3 \mathrm{l} / \mathrm{s}$ at $25^{\circ} \mathrm{C}$ and $17.9 \mathrm{l} / \mathrm{s}$ at $30^{\circ} \mathrm{C}$ was found to be 
required. Environments judged by a similar population as 'very fresh' would need higher amounts of fresh air.

Light is reviewed in a report by Veitch and Galasiu (2012), who cover in detail the effects on health. Light has a strong psychological effect on people, but reactions are linked with sensing the views out of the building, colour and spaciousness. Human perception is based on the reaction to stimuli from many sources at a particular instant.

The location of the building with respect to Nature is important. Ulrich (1984) showed how views out from hospital windows onto greenery improved patient recovery rates. Alvarsson, Weins, and Nilsson (2010) showed that the sounds of Nature aid physiological stress recovery. Greenery and still or running water refresh the body and spirit in any climate. There is growing evidence that landscape surrounding buildings can relieve occupants stress (Beil and Hanes 2013; Rainham, Cantwell, and Jason 2013).

The importance of quiet areas for locating buildings and the effect on people's health has been studied by Shepherd et al. (2013). The surfaces of buildings set the boundaries for sound. How a building sounds is just as important as how it looks (Shields 2003). The shape of interior spaces and the texture of surfaces determine the pattern of sound rays throughout the space. Every building has its own characteristic sound - intimate or monumental, inviting or rejecting, hospitable or hostile. A space is conceived and appreciated through its echo as much as through its visual shape, but the acoustic concept usually remains an unconscious background experience.

Buildings and systems need to be designed such that sound levels do not intrude on the activities undertaken in the space. Facades need to attenuate outside noise from entering the building. However, spaces can be too quiet, so one has to relate the sound level to the type of work being undertaken within the building.

Due to the now ubiquitous use of mobile phones, computers and other electronic equipment there is increasing electromagnetic pollution. However, the effects of this on health are still not well known (Clements-Croome 2000a, 2004b). Computers can cause eye strain, repetitive strain injuries, poor posture and associated aches and pains, so work patterns need to include 'breaks' for users to walk, stand and move around. Desks and chairs need to be adjustable to suit the body shape of the individual.

The effect of ionization on human health has always been debated. Nedved (2011) gives an up-to-date account of the knowledge in this area.

The word 'comfort' is perhaps overused. It has a neutral quality. Cabanac (2006) writes 
about pleasure and joy and their role in human life, and indicates how transients are important in pro- viding variety for the human sensory system to react to. 'Well-being' is a more comprehensive term. Ong (2013) presents a set of essays entitled Beyond Environmental Comfort, which stretch the meaning of comfort into new directions.

\section{The nature of productivity}

Improving productivity and well-being are the main drivers behind sustainability. (Jones Lang LaSalle 2013)

For an organization to be successful and to meet the necessary targets, the performance expressed by the productivity of its employees is of vital importance (Clements-Croome 2006). In many occupations, people work closely with computers within an organization that is housed in a building. Today, technology allows people to work while they are travelling or at home, and this goes some way to improving productivity. There are still, however, many people who have a regular workplace that demarcates the volume of space for private work but is linked to other workplaces and to social and public spaces. People produce less when they are tired, have personal worries or are suffering stress due to dissatisfaction with the job or the organization. The physical environment can enhance an individual's work and put people in a better mood, whereas an unsatisfactory environment can hinder work output.

Mental concentration is vital for good work performance. Absolute alertness and attention are essential if one is to concentrate. There is some personal discipline involved in attaining and maintaining concentration, but again the environment can be conducive to this by affecting one's mood or frame of mind; however, it can also be distracting and can contribute to a loss of concentration. A number of personal factors, which depend on the physical and mental health of an individual, and a number of external factors, which depend on the physical and social environment besides the work-related systems of management, influence the level of productivity.

Fisk (1999) has looked at the associations between the transmission of infectious disease, respiratory illnesses, allergies and asthma, sick building syndrome (SBS) symptoms, thermal environment, lighting and odours. He concluded that, in the USA, the total annual cost of respiratory infections is about $\$ 70$ billion and that of allergies and asthma is $\$ 15$ billion, and that a $20-50 \%$ reduction in SBS symptoms corresponds to an annual productivity increase of \$15-38 billion and, for office workers, there is a potential annual productivity gain of \$20-200 
billion. Fisk (2000a, 2000b) reported that, in the USA, respiratory illnesses cause the loss of about 176 million workdays and the equivalent of 121 million days of substantially restricted activity. Wheeler and Almeida (2006) state that good design makes business sense and UK surveys they undertook of professionals across different sectors and better working environments would make them nearly $20 \%$ more productive equivalent to $f 135$ bn per year. The UK Centre for Mental Health (2011) puts the costs of mental-related presenteeism (at work but unproductive) at $£ 15$ bn per year about twice that due to absenteeism and the built environment has a part to play in this together with organizational and social issues.

Fisk (1999) and Clements-Croome (2000a, 2000b) stated that, in office buildings, the salaries of workers exceed the building energy and maintenance costs and the annual construction rental costs by a factor of at least 25. Evans et al. (1998) concluded that business costs including salaries exceeded operating costs by $40: 1$ and capital costs by 200:1. This means that small increases in productivity, of $1 \%$ or less, are sufficient to justify additional capital expenditure to improve the quality of the building's services. Ultimately, this will result in a healthier working environment, as well as reduced energy and maintenance costs.

Fisk (1999) argues how poor air quality can affect the transmission of infectious disease and the incidence of respiratory illness, allergies and asthma, increase the likelihood of SBS and decrease worker performance. Air quality plays a major role in managing these issues. Air quality is a major issue because it only takes a few seconds for air to be inhaled and its effect to be transmitted to the bloodstream and hence the brain. Clean, fresh air is vital for clear thinking, but it is not the only issue to be considered.

The direct effects of poorly performing environments can be summarized as follows:

- Lost work hours due to sickness.

- Inability to reach true operational potential.

- Reduction in gross domestic product.

- Reduced company profit.

- A demoralized workforce.

- Increased operational and maintenance costs.

- Increased staff turnover.

The issue, therefore, becomes one of health risk and economic consequences. If organizational performance is a factor associated with the individual, then the building design 
should concentrate on user-centered design principles and on satisfying the occupant within the workplace.

In later work, Fisk, Black, and Brunner (2012) provide quantitative estimates of benefits and costs of providing different amounts of outdoor air ventilation in the US offices and its effect on SBS symptoms, work performance, short-term absence and building energy consumption. Some of the economic annual benefits were $\$ 13$ billion by increasing minimum ventilation rates from 8 to $10 \mathrm{l} / \mathrm{s}$ per person; \$38 billion by increasing from 8 to $15 \mathrm{l} / \mathrm{s}$ per person. The benefits of increasing minimum ventilation rates far exceeded any increased energy costs because the benefits yielded improved health and performance whilst decreasing absenteeism.

Roelofsen (2001) has described a study of 61 offices (7000 respondents) in the Netherlands which showed that people were off work for an average of 2.5 days/year because of unsatisfactory indoor environmental conditions. This represented a quarter of the total average absenteeism. Other work by Preller et al. (1990) and Bergs (2002) reveal a close correlation between sick leave and building-related health complaints.

\section{Effects of thermal environment and productivity}

It is probably true that most research and surveys about environmental conditions and their effects on performance have been concerned with temperature and indoor air quality. Much of this work is referenced in Clements-Croome (2004a, 2006 and 2013). In this article, the emphasis is in general on later work and also the wider range of environmental factors.

Cao and Wei (2005) described evidence which suggests that low temperatures tend to cause aggression, and high temperatures tend to cause aggression, hysteria and apathy. The question they investigated was 'Do temperature variations cause investors to alter their investment behaviour?' They hypothesized that lower temperature leads to higher stock returns due to investors' aggressive risk-taking, and higher temperatures can lead to higher or lower stock returns as aggression and apathy become competing effects on risk-taking. Here, we begin to see how the environment may affect decision-making. This is an issue that has been researched more recently by Satish et al. (2011, 2012).

Cui et al. (2013) carried out chamber room studies, using 36 subjects completing questionnaires and memory typing task, on the influence of temperature on human thermal comfort, motivation and performance. They concluded that learning was affected by temperature especially when it changed frequently; warm discomfort was more detrimental 
to performance and motivation than cold discomfort and so recommended a slightly cool to neutral setting (this would correspond to Fangers predicted mean vote in the range $0-0.5$; the changes in performance they thought were caused more by a change in motivation than a change in temperature.

The underlying mechanisms explaining how temperature affects performance are beginning to be probed and understood. Lan et al. (2011), for example, found that an increase in $\mathrm{CO}_{2}$ in the blood decreases oxygen saturation in the blood both of which are likely to affect mental work but many questions remain.

In addition to this, the work of Bakó-Biró et al. (2012) on the effects of $\mathrm{CO}_{2}$ on learning has been mentioned and other work referenced there and in Wyon and Wargocki (2013) support the contention that the physical environment affects performance. There remain many more questions that need research and Wyon and Wargocki identify some of these but there is enough evidence already to encourage designers to take a more holistic and in-depth view of the conditions they provide for building occupants.

\section{Measurement of productivity}

It is often said that productivity cannot be measured, but the following four approaches have had some success. In their work on the effect of environment on productivity, ClementsCroome and Li (2000) have proposed a holistic model that considers the impact of the social ambience, organization, well-being of the individual and physical-environment factors, and have derived relationships between productivity and job satisfaction, stress, physical environment, SBS and other factors. The data collected from office surveys were analysed using the Analytical Hierarchical Process. This multifunctional approach resulted in a diagnostic tool that can be used to assess weak and strong factors in any given internal the environment.

Another practical approach is given by Wargocki et al. (2006), who have proposed a method for integrating productivity into the life-cycle cost analysis of building services.

Yet another practical route to evaluating productivity has been described by Juniper, White, and Bellamy (2009).

Satish et al. $(2011,2012)$ have used a strategic management simulations methodology to measure the process of thinking and the impact of environmental factors on decision-making. Satish believes that productivity is a function of decision-making at various levels and so the built environment is a significant factor. 
Reliable methodologies are evolving that will produce the evidence we need to convince clients to invest in better buildings, which will help to improve staff performance and increase value for money - bearing in mind that about $90 \%$ of the costs of running a typical commercial office building is the staff salaries.

A lack of productivity shows up in many ways, such as absenteeism, arriving late and leaving early, over-long lunch breaks, careless mistakes, overwork, boredom and frustration with the management and the environment.

Agha-Hossein et al. (2013) compared occupant's reactions to the environment in two buildings and used POE techniques to assess employees perceived productivity, well-being and enjoyment at work. She refers to the work of Meyer (1999), Vischer (2008) and others that show how an enjoyable workplace with a stimulating physical environment can improve occupants morale, satisfaction, perceived well-being and productivity and Agha-Hosseins' research confirms this.

Leaman and Bordass have carried out POE over many years and conclude that when occupants are satisfied with their overall comfort then productivity tends to increase. The term overall comfort is a mixture of things including personal health and mood besides functional, convenience and environmental factors (2006, 161, Chapter 10).

\section{Sick building syndrome}

SBS is defined as $20 \%$ of a building's occupants complaining of a similar medical condition, while in the building, due to an unknown cause over a period of at least 2 weeks (AbdulWahab 2011). Some research has questioned whether the underlying factors of SBS are perhaps biased to those who complain more than others, or those who are more sensitive and more susceptible to environmental influences.

Many surveys have shown that people can feel unwell when they are working in a building but recover when they leave it. The WHO (1993) stated the symptoms typical of SBS include stuffy or runny nose, dry skin, chest tightness, watering or itchy eyes, headache, lethargy and loss of concentration (Singh 1996). Many studies since show that the symptoms are usually respiratory or cerebral (including headaches, unusual tiredness and lethargy), associated with the eyes or skin, or musculoskeletal discomfort. Symptoms may manifest as minor irritations or even as pain.

Health is the result of a complex interaction among the physiological, psychological, personal and organizational resources available to individuals and the stress placed upon 
them by their physical and social environment and work and home life. A deficiency in any area increases stress and decreases human performance. Research by Weiss (1997) at Rochester University in New York suggested that the mind can affect the immune system. Stress can decrease the body's defences and increase the likelihood of illness, resulting in a reduction in well-being. Stress arises from a variety of sources: the organization, the job, the person and the physical- environmental conditions. It can affect the mind and the body, weaken the immune system and leave the body more vulnerable to environmental conditions. In biological terms, the hypothalamus reacts to stress by releasing adrenocorticotropic hormone, which in turn increases the amount of the hormone cortisol in the blood to a possibly damaging level and affecting the brain cells involved in memory. This chain of events interferes with human performance, and productivity falls as a consequence.

People spend about $90 \%$ of their lives in buildings, so the internal environment has to be designed to limit the possibilities of infectious disease, allergies and asthma, and buildingrelated health symptoms, referred to as 'SBS symptoms'. Anything in the environment that blocks or disturbs the sensory systems in an undesirable way will affect health and work performance. Thus, lighting, sound, air quality and thermal climate are all conditions around us that affect our overall perception of the environment.

\section{Well-being}

The most successful organisations are now turning their attention to employee well-being as a way to gain emotional, financial and competitive advantage. (Rath and Harter 2010)

Steelcase Inc. has Workspace Futures teams in the USA, Europe and Asia exploring how the physical workspace influences behaviour. Human interaction is key. Of course, there are some occupations such as writing, composing music, sculpting or painting that involve a lot of home or atelier working and here the individual creates the environment which suits them. Wellbeing is a systemic and holistic measure which integrates many facets including the physical, cognitive and psychological needs of people.

The WHO states: 'Health is a state of complete physical, mental and social well-being and not merely the absence of disease or infirmity'.

The term 'well-being' reflects one's feelings about oneself in relation to the world. There is a growing interest in well-being, and in the UK well-being research centres include those at 
Warwick University (Well-being in Sustainable Environments - WISE) (Burton et al. 2011), Cranfield University (Juniper, White, and Bellamy 2009) and the Institute of Well-Being at Cambridge University (Anderson and French 2010; Huppert, Baylis, and Keverne 2005).

Warr (1998a, 1998b) proposed a view of well-being that comprises three scales: pleasure to displeasure, comfort to anxiety and enthusiasm to depression. Steemers and Manchanda (2010) have proposed another definition attributes that encompasses health, comfort and happiness (Chappells 2010). There are job and outside work attributes that characterize one's state of well-being at any point in time and these can overlap with one another. Bluyssen (2014) writes extensively about how to assess occupants' well-being in buildings.

Well-being is only one aspect of mental health; other factors include personal feelings about one's competence, aspirations and degree of personal control. Well-being is connected with overall satisfaction, happiness and quality of life, and is thus a much more encompassing word than comfort reflecting a more complex multi-dimensional concept.

We experience life through our senses, and the environment we provide for people to interact with is important. A building and its environment can help people produce better work, because they are happier and more satisfied when their minds are concentrated on the job in hand; good building design can help achieve this. At low and high levels of arousal or alertness, the capacity for performing work is low; at the optimum level, the individual can concentrate on work while being aware of peripheral stimuli from the physical environment. Different types of work require different environmental settings for an optimum level of arousal to be achieved. It is necessary to assess if a sharper or leaner indoor environment is required for the occupants' good health and high productivity, and to redefine comfort in terms of well-being.

Giddings, Thomas, and Little (2013) surveyed 16 workplaces in different companies to assess how the physical environment affected the users' perception of stimulation. The underlying argument here is that there is an optimal level of arousal is required for focusing attention on work. The most significant predictors of stimulation levels and perceived productivity were spatial layout, temperature, air movement, comfort with reference to the ergonomics of the workplace, greenery, personal control of the climate, artwork, colour and break out areas. As is a common experience the arousal or alertness levels were found to be best in the morning but fell significantly after the lunch break. Power napping is one way to counteract this but some of these environmental factors were found to help too. They also recommended more user centric design. Work reported in the UK publication Times Higher Education 
(Newman 2010) reviewed the impact of well-being on staff and research performance. The Higher Education Funding Council for England is encouraging universities to invest in well-being, which can reduce absenteeism and staff turnover. A report commissioned by the Health Work Wellbeing Executive, UK, stated that for every $£ 1$ spent, well-being brings a return of $£ 4.17$ (PriceWaterhouseCoopers LLP 2008), and Daly (2010) has made a similar evidence-based case for hospitals.

Well-being depends on the management ethos of the organization, the social ambience and personal factors, but the physical environment also has a major role to play (ClementsCroome 2004a, 2004b). Anderson and French (2010) have discussed the deeper significance of well- being, and Heschong (1979) has reported that productivity tends to be increased when occupants are satisfied with their environment. The proposal here is that well-being is achieved when all the factors in Maslow's pyramid of needs are satisfied (Table 1). In his motivationhygiene theory, Herzberg (1966) distinguished between 'hygiene' factors (e.g. salary, working conditions and fringe benefits), which can prevent dissatisfaction, and motivational factors (e.g. achievement, responsibility and recognition), which actually lead to improved effort and performance. Evans and Stoddart (1990) proposed a socio-ecological model of health (Figure 1) wherein the environmental and genetic sources of stimulation lead to individual responses and behaviour stemming from our state of well-being.

Morris et al. (2006) developed the drivers-pressures-state-exposure-effects-actionscontext (DPSEEA) model (Table 2) which is based on earlier work by the WHO which illustrate how social, economic, environmental and political drivers lead to impacts on health and wellbeing, and require action to improve them. Figure 2 shows the pathway from the drivers that act on the environmental systems and result in levels or states of sound, light, heat and air quality, for example, to which human beings are exposed. This impacts on their physiological and psycho- logical systems, and causes positive or negative states of health and well-being. Measurements can be made to help determine what actions should be implemented.

\section{Well-being and productivity}

Warr (1998a, 1998b) has described 10 features of jobs that have been found to be associated with well-being. He believes that stable personality characteristics and age and gender are also significant. Environmental determinants of well-being are described as the opportunity for personal control, the opportunity to use ones skills, externally generated goals, variety, the environment, availability of money, physical security, supportive supervision, the opportunity 
for interpersonal contact and job status in society. Warr (1998a, 1998b) reviews work which indicates that greater well-being is significantly associated with better job performance, lower absenteeism and a lower probability of the employee leaving the organization. Both the organization and personal factors play a role.

Table 1. Maslow's hierarchy of needs in the workplace (Maslow 1943).

Need

Achieved through

Physiological catering Safety

Social esteem

Self-

actualisation
Good working conditions, attractive salary, subsidized housing, free

Private health care, pension, safe working conditions, job security

Group relationships, team spirit company sports, office parties, informalactivities, open communication

Regular positive feedback, prestigious job titles, write-up in company news sheet, promotion and reward

Challenging job, discretion over work activity, promotion opportunities, encouraging creativity, autonomy and responsibility

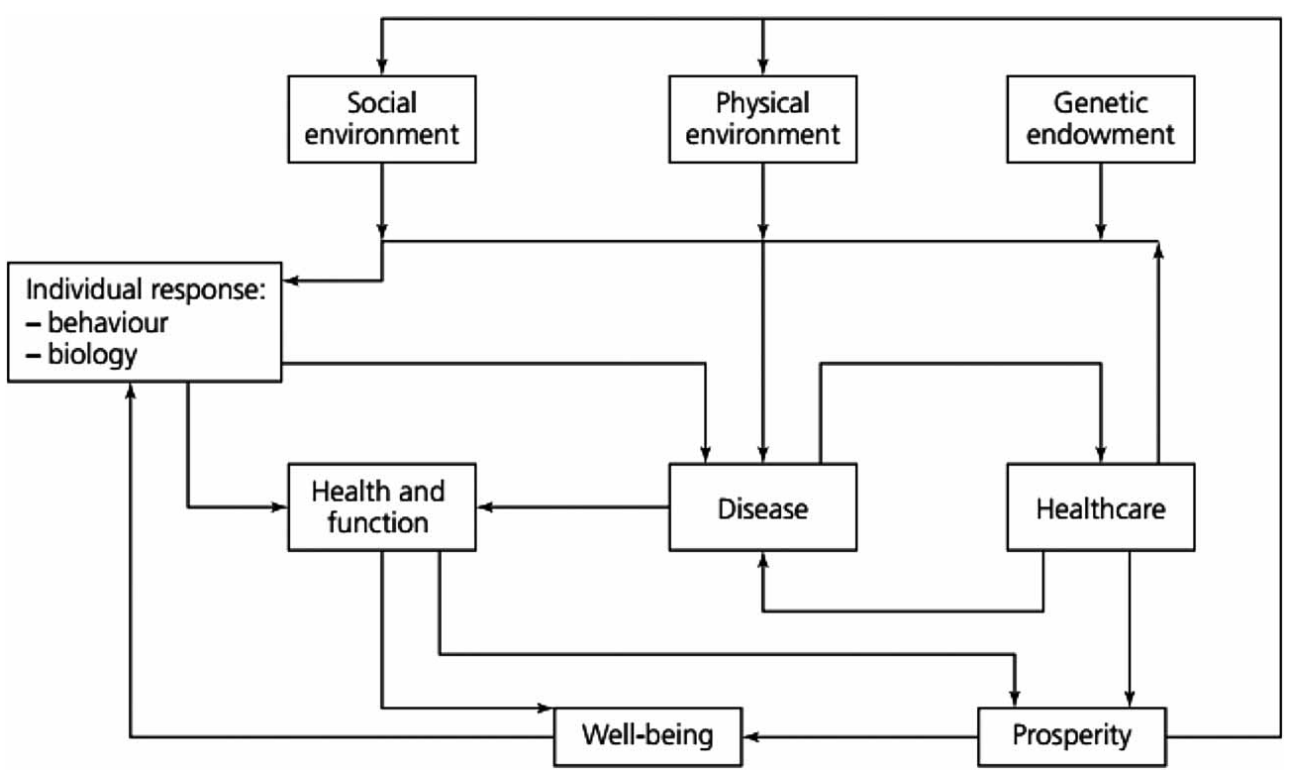

Figure 1. Evans and Stoddart's socio-ecological model of health (Evans and Stoddart 1990; Morris et al. 2006). 
Heerwagen (1998) draws attention to work in organizational psychology which shows that the relationship between buildings and worker performance can be calculated as Performance $=$ Motivation $\times$ Ability $\times$ Opportunity.

An individual has to want to do the task, and then has to be capable of doing it; and, last but not least, resources and amenities have to be available so that the task can be done. The built environment provides a physical and social ambience that affects motivation; the provision of individual control and a healthy environment can enable ability to flourish; communications systems, restaurants and other amenities aid workers' motivation and ability even further, by providing opportunities for task implementation.

Table 2. Elements of the modified DPSEEA context model (Morris et al. 2006).

\begin{tabular}{ll}
\hline Element & \multicolumn{1}{c}{ Description } \\
\hline Drivers & Society level: social, economic or political influences on the environment \\
Pressures Factors resulting from drivers that act to modify or change the environmental state \\
State & The resultant environment that has been modified due to the pressure \\
Exposure & Human interaction with the modified environment \\
Effects & Human health effects \\
Actions & Policy and practice designed to address particular factors identified in the chain \\
Context & Individual level: social, economic and demographic factors that influence a person's exposure \\
& to the modified environment or which lead to a health effect
\end{tabular}

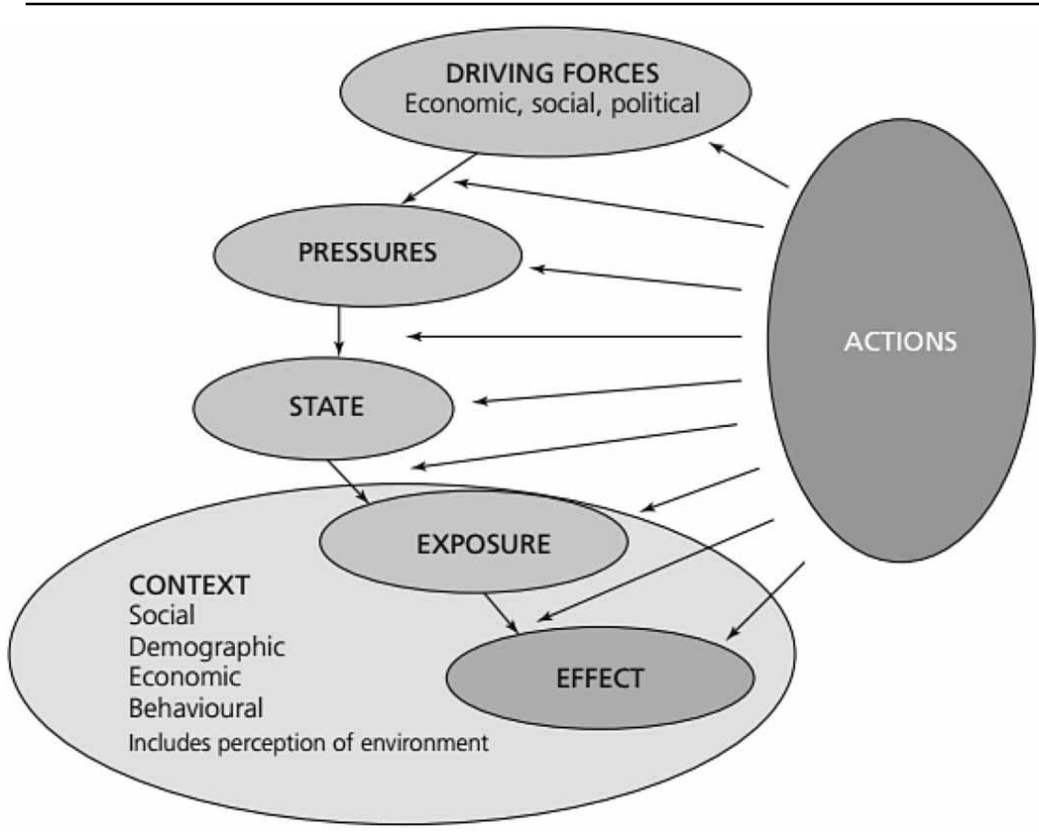

Figure 2. The modified DPSEEA context model. Reprinted with permission from Morris et al. (2006), 
Buildings moderate climates, which helps to keep the body healthy and enhance wellbeing. Some buildings demand closely controlled environments, and various systems can be installed in order to achieve this, but many buildings can take advantage of the body's ability to adapt and interact in a compensatory way with other senses. Increasingly, wireless sensor networks will link a building directly with the occupant by means of sensors embedded in the building structure and in the clothing people wear. We will be able to monitor our personal reactions and responses to the environment.

If we are to understand how we can construct more productive environments, we have to understand more about the nature of work and how the human system deals with work. Quality, and hence productive, work means we need good concentration. When we are about to carry out a particular task we need to settle down, get in the mood and then concentrate. Our attention span usually lasts for about 90-120 minutes and then natural fatigue comes into play and our concentration drops, but with a creative break we pick up again, concentrate for another spell of time, and the pattern repeats itself over the waking day. This is the so called ultradian rhythm. De Marco and Lister (1987) have described this as a concept of flow. Mawson (2002) describes their work, which claims that individuals take about 15 minutes to ramp up to their concentration level. When an individual is in a state of flow he or she may be distracted or may become naturally tired, and the process then repeats itself. Mawson (2002) believes that there is a significant loss of productivity from distraction, which for a well-managed office has been identified by the Harvard Business Review (17 May 2012) as being approximately 70 minutes of lost productivity in a typical 8-hour day. This distraction is mainly due to general conversation and phones. Digital technology can also be a source of lost time if it is not reliable. The constant interruptions of emails and texts can reduce productivity leaving people feeling tired and lethargic according to a survey by Taylor Nelson Sofres Research (Wilson 2010). The rapid development in technology is very helpful in some ways, but it has brought with it some negative issues. These are described by van der Voordt (2003) and include getting used to technology, concentration, Information and Computer Technology problems and time loss associated with logging onto computer systems and searching for information.

Davidson (2003) and Davidson and Begley (2012) led a research study at the University of Wisconsin-Madison which showed that positive thinking (good mood and optimism) can promote good health because the body's defences (the immune system) are stronger. This suggests that the balance between the mind and the body is a sensitive one. So how relevant 
is this in the workplace? Various stressors can arise from conflicts within the physical, social organizational environment. People adapt to these stressors in various ways, but some will be weakened and, if conditions are very stressful, many will be affected.

There is substantial evidence, as described by Heerwagen (1998), that positive mood is associated with the physical environment and everyday events such as social interactions (Clark and Watson 1988). Even more telling is research which has shown that a positive mood aids complex cognitive strategies (Isen 1990), whereas a negative mood due to distractions, discomfort, health risks or irritants arising from the physical or social environments restrict attention and hence affect work performance. Because positive moods directly affect the brain processes (Le Doux 1996), it can be concluded that many aspects of building environmental design can enhance task performance. Heerwagen (1998) distinguishes between direct effects, such as over- heating, noise or glare, and indirect effects arising from mood and/or motivational factors. Several positive-mood-inducing factors have already been mentioned - aesthetics, freshness, daylight, view, colour, personal control, spatial aspects and nature.

Our understanding about how the brain works is deepening all the time. Questions remain on how we concentrate and focus even though there is much known about attention (Pashler 1998). Carter (2014) distinguishes between focused attention, sustained attention, selective attention, alternating attention (switching from one topic or person to another) and divided attention (multi -tasking). Brain wave patterns of activity are classified as follows:

\begin{tabular}{lll}
\hline Delta & $2-4 \mathrm{~Hz}$ & Deep sleep \\
Theta & $4-7 \mathrm{~Hz}$ & Meditation, light sleep \\
Alpha & $7-14 \mathrm{~Hz}$ & Relaxation, creative thought \\
Beta & $14-20 \mathrm{~Hz}$ & Everyday thinking \\
Gamma & $25-100 \mathrm{~Hz}$ & Integrates brain information, regulates memory processing \\
\hline
\end{tabular}

One can learn to meditate and relax and courses such as Optimizing Brain Fitness are available at, for example, the School of Medical and Health Sciences at The George Washington University. Meditation or bio-feedback methods are well known. But also we should be designing 'creative thinking workplaces' for encouraging alpha brain mode activity to flourish. There is much to learn yet but this would be a very radical approach that is based on an understanding of how we think when multi-tasking or focusing on particular facets of tasks. The environment triggers moods, thoughts and emotions and brain wave activity is an indicator of these. 
Mood, feelings and emotions affect people's decision-making. Mood can be influenced by a wide complexes of environmental factors, such as the 'Monday effect' or weather conditions. A body of psychological literature shows that temperature is one of the important meteorological variables that affect people's mood, and this in turn influences behaviour. Cao and Wei (2005) stated that the research to date has revealed that stock market returns are associated with nature-related variables such as the amount of sunshine, the daylightsaving time change, the length of the night and the lunar phases of the moon. Nevertheless, as has been stated already, their work shows that the internal built environment plays a very significant role in affecting how people feel.

\section{Conclusions}

The internal built environment matters in all the ways that have been described in Ong (2013): it is an intrinsic part of our existence. Betthaeuser (2013) calls for a new effective and economic work place model. His argument is that people are beginning to view their workplace in a more emotional way because the office can offset the brutality of the news media and transport stress. The workplace can be a kind of sanctuary offering safety, enjoyment and a place to fulfil creativity. He believes that we need to provide a more organic and responsive place to meet occupants needs. These thoughts are echoed in Creating the Productive Workplace (Clements-Croome 2006 and in the earlier 2000 edition) where a model for productivity which embraced social, personal, organizational and environmental factors together was advocated. Flexible approaches to workplace design are the hallmark of the Workplace Trends Report 2012 published by Sodexo.

Apple have started to work on their new offices to be located in Cupertino in San Francisco Bay and aspire to design and build the best office building in the world (The Times Technology Review, November, 2013,4-5) and the universal credit given to Apple products will imbue the eyes of the world with high expectations. Step into a cathedral, a restaurant or an office and feel the ambience they offer. This can affect ones mood, well-being and work effort as an individual or as a team. Space can be patterned to encourage formal or informal working so in a way condition human behaviour. There are many subtle factors we need to know more about, for example, do high ceilings encourage abstract thought and creativity as some believe (Meyers-Levy and Zhu 2007)? Often assumptions about higher occupancy densities or low ceiling heights are made on a cheap cost basis but may in the end have human consequences which make them more expensive. Designing for function and convenience 
alone is not enough. In the words of Volker Buscher (Director at Arup) (McMeeken 2014):

I think we are going to see the Age of the 'humane' engineer - engineers who think not just about functions but also about emotions.

The emphasis today in designing workplaces is on creativity. There is an eagerness to understand how we work effectively and happily whether as teams or individuals. Pentland (2014) in his book Social Physics believes that the divide between 'hard' and 'soft 'sciences is disappearing. Social physics is about idea flow, the way human social networks spread ideas and transform those ideas into behaviours. Brainstorming is not new but enabling this to happen in the daily work routine in a natural way is the root of achieving creative environments.

I am a believer in creative process and am fascinated by the idea that environment, both physical and cultural, can make or break creativity. I feel that it is possible to define what helps to cultivate creativity in a corporate environment that the physical space can be used as a tool within the creative process and is not a mystifying intangible that we can only hope to stumble on. (Groves 2010)

In her book Groves proves this belief by describing the experiences she had when visiting some of the worlds most successful brands and creative companies. She found four categories of creative spaces. Those that stimulate, those for reflection, those for collaboration and those to have fun in. Organizations need a mixture of these things.

After all the design is done and operating there remains the occupant with all their unique qualities, expectations and personal habits, likes and dislikes. Shawn Achor is a passionate advocate of positive thinking and he suggests that everyone should try and make room each day for recognizing some meaningful event and time for some fun, meditation, generosity, kindness and gratitude. The time spent on these actions can be small but the rewards are vast. The building can provide the setting but we as individuals have to be receptive and proactive too.

Since this article was written I have extended the work in an EU Report see ClementsCroome (2014) to include a section on Beyond Environmental Comfort. In this I develop the idea that the word 'comfort' is perhaps overused. It has a neutral but long-term durable quality. It is usually seen as a pleasant or relaxed state of a human being in relation to their 
environment but surely that is only part of what we need for the concentrating mind? Is one highly attentive when comfortable or is there a danger of being bored, losing attention or even falling asleep? Pleasure and joy play an important role in everyday life. Transients are important in providing variety and contrast for the human sensory system to respond to. During the day we hope for and seek joyful moments perhaps a tree in blossom, pleasant air movement or changing light patterns. There is an echo of this in Maslow's book Religions, Values and Peak Experiences in 1964 when he writes about peak experiences which can be transitory, momentary or longer term but trigger happiness and uplift in mood. The term alliesthesia means that a stimulus may give rise to a pleasant or unpleasant sensation depending on the internal state of the person. Our experience of the environment is the result of an interplay of heat, light, sound and many other factors. Buildings provide a multi-sensory experience. The senses need stimulation to react to otherwise boredom sets in.

\section{References}

Abdul-Wahab, S. A. 2011. Sick Building Syndrome in Public Buildings and Workplaces. Chap. 13. The Interaction Between the Physical Environment and People (edited by Clements-Croome D J). Berlin: Springer-Verlag.

Agha-Hossein, M. M., S. El-Jouzi, A. A. Elmualim, J. Ellis, and M. Williams. 2013. "Post-occupancy Studies in an Office Environment: Energy Performance and Occupants' Satisfaction." Building and Environment 69: 121-130.

Alvarsson, J. J., S. Weins, and M. E. Nilsson. 2010. "Stress Recovery During Exposure to Nature Sound and Environmental Noise." International Journal of Environmental Research and Public Health 7 (3): 1036-1046.

Anderson, J., and M. French. 2010. Sustainability as Promoting Well-being: Psychological Dimensions of Thermal Comfort. Cambridge: Personal communication, Institute of Well-Being, University of Cambridge.

Bakó-Biró, Z., D. J. Clements-Croome, N. Kochhar, H. B. Awbi, and M. J. Williams. 2012. “Ventilation Rates in Schools and Pupils' Performance." Building and Environment 48: 215-223.

Bakó-Biró, Z. S., N. Kochhar, D. J. Clements-Croome, H. B. Awbi, and M. Williams. 2008. "Ventilation Rates in Schools and Pupils' Performance Using Computerised Assessment Tests." Proceedings of the 11th International Conference on Indoor Air Quality and Climate, Copenhagen, Sweden.

Baron, R. A. 1990. "Environmentally Induced Positive Effect: its Impacts on Self-efficacy, Task Performance, Negotiation and Conflict." Journal of Applied Social Sociology 20 (5): 368-384.

Beil, K., and D. Hanes. 2013. "The Influence of Urban Natural and Built Environments on Physiological and 
Psychological Measures of Stress - A Pilot Study." International Journal of Environmental Research and Public Health 10 (4): 1250-1267.

Bell, J., J. Mabb, V. Garcia-Hansen, B. Bergman, and L. Morawska. 2003. "Occupant Health and Productivity: An Australian Perspective." Proceedings of the CIB 2003 International Conference on Smart and Sustainable Built Environment (SASBE 2003) (Edited by Yang J., P.S. Brandon, and A.C. Sidwell), pp. 687-694.

Bergs, J. 2002. "The Effect of Healthy Workplaces on the Well-being and Productivity of Office Workers." Plants for People Symposium, Reducing Health Complaints at Work, Amsterdam.

Bernstein, H., and M. Russo. 2013. "Smart Market Report." McGraw-Hill Construction (MHC_Analytıcs@mcgraw-hill.com).

Betthaeuser, G. 2013. “Leesman Review." Issue 10 page 2.

Bluyssen, P. M. 2014. The Healthy Indoor Environment: How to Assess Occupants' Well-Being in Buildings.

Oxford: Routledge.

Boyden, S. 1971. "Biological Determinants of Optimal Health." In The Human Biology of Environmental. Burton, E. J., W. Bird, A. Maryon-Davis, M. Murphy, S. Stewart-Brown, K. Weare, and P. Wilson. 2011. “In Thinking Ahead: Why We Need to Improve Children's Mental Health and Wellbeing (Edited by Jolley R)." London: Faculty of Public Health of the Royal College of Physicians of the United Kingdom.

Cabanac, M. 2006. "Pleasure and Joy, and their Role in Human Life." In Creating the Productive Workplace, edited by D. Clements-Croome, 40-50. London: E \& FN Spon.

Cao, M., and J. Wei. 2005. "Stock Market Returns: A Note on Temperature Anomaly." Journal of Banking \& Finance 29: 1559-1573.

Carter, R. 2014. The Brain Book. 2nd ed. London: Dorling Kindersley (DK).

Chappells, H. 2010. "Comfort, Well-being and the Socio-technical Dynamics of Everyday Life." Intelligent Buildings International 2 (4): 286-298.

Chrenko, F. A., ed. 1974. Bedford's Basic Principles of Ventilation and Heating. 3rd ed. London: HK Lewis, Chap. VIII, pp. 154-180.

CIBSE (Chartered Institution of Building Services Engineers). 1999. "Environmental Factors Affecting Office Worker Performance: A Review of the Evidence. Technical Memorandum 24." London: CIBSE. Clark, L. A., and D. Watson. 1988. "Mood and the Mundane: Relationships Between Daily Life Events and Self-reported Mood." Journal of Personality and Social Psychology 54: 296-308.

Clements-Croome, D. J. 2000a. "Computers and Health in the Work Place." Proceedings of Healthy Buildings, University of Technology. Helsinki 1: 119-124.

Clements-Croome, D. J. 2000b. Creating the Productive Workplace. London: Spoon-Routledge.

Clements-Croome, D. J. 2004a. Intelligent Buildings: Design, Management \& Operation. London: Thomas Telford.

Clements-Croome, D. J. 2004b. Electromagnetic Environments and Health in Buildings. London: Spon. 
Clements-Croome, D. J. 2006. Creating the Productive Workplace. London: Spon-Routledge.

Clements-Croome, D. J. 2008. "Work Performance, Productivity and Indoor Air." Scandinavian Journal of Work Environment and Health Supplement 4: 69-78.

Clements-Croome, D. J. 2013. Intelligent Buildings: Design, Management \& Operation. London: ICE.

Clements-Croome, D. J. 2014. "Sustainable Intelligent Buildings for Better Health, Comfort and WellBeing." Report for DENZERO project supported by the TÁMOP-4.2.2.A-11/1/KONV-2012-0041 and co-financed by the European Union and the European Social Fund (d.j.clements-croome@reading.ac.uk)

Clements-Croome, D. J., and B. Li. 2000. "Productivity and Indoor Environment." Proceedings of Healthy Buildings Conference, University of Technology. Helsinki 1: 629-634.

Construction Industry Council. 2002. Design Quality Indicator. Accessed March 26, 2013. http://www.dqi. org.uk

Conti, F. 1978. Architecture as Environment. London: Harcourt Colleges.

Cui, W., Guoguang Cao, Jung Ho Park, Qin Ouyang, and Yingxin Zhu. 2013. "Influence of Indoor Air Temperature on Human Thermal Comfort, Motivation and Performance." Building and Environment 68: 114-122.

Daly, S. 2010. "Eco Build Conference." London and Personal Communication. Heath Avery.

Davidson, R. J. 2003. “Report by M. Henderson.” The Times, September 2, p. 4.

Davidson, R. J., and S. Begley. 2012. The Emotional Life of your Brain. New York, NY: Penguin.

De Marco, T., and T. Lister. 1987. People Ware: Productive Projects and Teams. New York: Dorset House. Dumber, W. N., J. S. Warm, and R. Parasuraman. 1995. "Olfactory Stimulation and Sustained Attention." In Compendium of Olfactory Research. Explorations in Aromachology: Investigating the Sense of Smell and Human Response to Odours, 1982-1994, edited by A. N. Gilber, 39-46. Dubuque, IA: Kendall Hunt.

Eley Associates. 2001. The Collaborative for High Performance Schools, Best Practices Manual. San Francisco, CA: Eley Associates.

Evans, R., R. Harlot, N. Haste, and Jones. 1998. "The Long Term Costs of Owning and Using Buildings, Royal Academy of Engineering in London, also in Designing Better Buildings: Quality and Value in the Built Environment." Edited by Sebastian Macmillan (Taylor and Francis) pp. 42-50, ISBN 0- 41531525-5.

Evans, R., and G. Stoddart. 1990. "Producing Health, Consuming Health Care." Social Science Medicine 31: 1347-1363.

Fanger, P. O. 2002. "Human Requirements in Future Air-conditioned Environments." Advances in Building Technology 1: 29-38.

Fisk, W. J. 1999. "Estimates of Potential Nationwide Productivity and Health Benefits from Better Indoor Environments: An Update." Chap. 4 in Indoor Air Quality Handbook, edited by J. D. Spengler, J. M. Samet, and J. F. McCarthy. New York: McGraw-Hill. 
Fisk, W. J. 2000a. "Health and Productivity Gains from Better Indoor Environments and their Relationship with Building Energy Efficiency." Annual Review of Energy Environment 25 (1): 537-566.

Fisk, W. J. 2000b. "Review of Health and Productivity Gains from Better IEQ." Proceedings of Healthy Buildings, Helsinki 4: 24-33.

Fisk, W. J., D. R. Black, and G. Brunner. 2012. “Changing Ventilation Rates in US Offices: Implications for Health, Work Performance, Energy, and Associated Economics." Building and Environment 47: 368372.

Gensler. 2013. "Workplace Survey." http://www.gensler.com/uploads/documents/2013

Giddings, B., J. Thomas, and L. Little. 2013. "Evaluation of the Workplace Environment in the UK, and the Impact on Users' Levels of Stimulation." Indoor Built Environment 22 (6): 965-976.

Groves, K. 2010. I Wish I Worked There! (A Look Inside the Most Creative Spaces in Business). Chichester: John Wiley and Sons.

Heerwagen, J. H. 1998. "Productivity and Well-being: What are the Links?" American Institute of Architects Conference on Highly Effective Facilities. Cincinnati, $\mathrm{OH}$, USA.

Herzberg, F. 1966. Work and the Nature of Man. New York: World Publishing Company.

Heschong, L. 1979. Thermal Delight in Architecture. Cambridge: MIT Press.

Huppert, F. A., N. Baylis, and B. Keverne. 2005. The Science of Well-Being. Oxford: Oxford University Press.

Isen, A. M. 1990. "The Influence of Positive and Negative Effect on Cognitive Organisation: Some Implications for Development." In Psychological and Biological Approaches to Emotion, edited by N. Stein, B. Leventhal, and B. Trabasso, 1-95. Hillsdale, NJ: Erlbaum.

Jones Lang LaSalle. 2013. "Occupier Special Sustainability." White Paper, Advance Publications, www. joneslanglasalle.com

Juniper, B. A., N. White, and P. Bellamy. 2009. “Assessing Employee Well-being -Is There Another Way?" International Journal of Workplace Health Management 2 (3): 220-230.

Knasko, S. C. 1993. "Performance Mood and Health During Exposure to Intermittent Odours." Archives of Environmental Health 48 (5): 305-308.

Koegelenberg, I. 2014. “Green Buildings and Employee Wellness: Fact or Fiction?” RACA Journal 29 (12): 27-33.

Lan, L., P. Wargocki, D. P. Wyon, and Z. Lian. 2011. "Effects of Thermal Discomfort in an Office on Perceived Air Quality, SBS symptoms, Physiological Responses and Human Performance." Indoor Air 21: 376-390.

Leaman, A., and W. Bordass. 2006, Chap. 10 in Creating the Productive Workplace, edited by D. ClementsCroome. Oxford: Taylor and Francis.

Le Doux, J. 1996. The Emotional Brain. New York: Simon and Schuster.

Ludvigson, H. W., and T. R. Rottman. 1989. "Effects of Odours of Lavender and Cloves on Cognition, Memory, Affect, and Mood." Chemical Senses 14 (4): 525-536. 
Maslow, A. H. 1943. "A Theory of Human Motivation." Psychology Review 50 (4): 370-396.

Mawson, A. 2002. The Workplace and Its Impact on Productivity. London: Advanced Workplace Associates.

McMeeken, R. 2014. "Building 2050: The Cities of the Future." CIBSE Journal, January, Careers Special Supplement, pp. 22-24.

Mendell, M., W. J. Fisk, K. Kreiss, H. Levin, D. Alexander, W. S. Cain, J. R. Girman, et al. 2002. “Improving the Health of Workers in Indoor Environments: Priority Research Needs for a National Occupational Research Agenda." American Journal of Public Health 92 (9): 1430-1440.

Meyer, H. 1999. "Fun for Everyone." Journal of Business Strategy 20 (2): 13-17.

Meyers-Levy, J., and R. Zhu. 2007. "The Influence of Ceiling Height: The Effect of Priming on the Type of Processing That People Use." Journal of Consumer Research 34 (August): 174-186.

Miller, N. G., D. Pogue, Q. D. Gough, and S. M. Davis. 2009. "Green Buildings and Productivity." Journal of Sustainable Real Estate 1 (1): 65-91.

Morris, G. P., S. A. Beck, P. Hanlon, and R. Robertson. 2006. "Getting Strategic about the Environment and Health." Public Health Journal 120: 889-903.

Nedved, M. 2011. "Ventilation and the Air lon Effect in the Indoor Environments: Impact on Human Health and Well-being." Chap. 28 in Building Sick Syndrome in Public Buildings and Workplaces, edited by S. A. Abdul-Wahhabi. Berlin: Springer-Verlag.

Newell, G. 2009. “Developing a Socially Responsible Property Investment Index for UK Property Companies." Journal of Property Investment \& Finance 27 (5): 511-521.

Newman, M. 2010. “Get Happy, and Get on with it.” Times Higher Education 34-36.

Nicol, F., M. Humphreys, and S. Roaf. 2012. Adaptive Thermal Comfort: Principles and Practice. London: Routledge.

Oh, S. Y. J. 2005. "Indoor Air Quality and Productivity in Offices in Malaysia." BSc diss., School of Construction Management and Engineering, University of Reading, Reading, UK.

Ong, B. L. 2013. Beyond Environmental Comfort. London: Routledge.

Pashler, H. E. 1998. The Psychology of Attention. Cambridge, MA: The MIT Press.

Pentland, A. 2014. Social Physics. New York, NY: The Penguin Press.

Preller, L., T. Zweers, B. Brunekreef, and J. S. M. Boleiji. 1990. “Indoor Air Quality '90.” Fifth International Conference on Indoor Air Quality and Climate 1: 227-230.

PriceWaterhouseCoopers LLP. 2008. "Building the Case for Wellness." http://www.dwp.gov.uk/docs/hwwb- dwp-wellness-report-public.pdf(26/3/2013)

Rainham, D., R. Cantwell, and T. Jason. 2013. "Nature Appropriation and Associations with Population Health in Canada's Largest Cities." International Journal of Environmental Research and Public Health 10 (4): 1268-1283.

Rath, T., and J. K. Harter. 2010. Well-Being: The Five Essential Elements. New York, NY: Gallup Press. Roelofsen, P. 2001. "The Design of the Workplace as a Strategy for Productivity Enhancement." Presented 
at the7th REHVA World Congress, Clima 2000, Naples, Italy.

Rotton, J. 1983. "Affected and Cognitive Consequences of Malodorous Pollution." Basic and Applied Psychology 4 (2): 171-191.

Satish, U., J. F. William, J. M. Mark, E. Ekaterina, H. Toshifumi, P. S. Douglas, B. C. Lisa, S. Krishnamurthy, and

T. Kaeling 2011. "Impact of CO2 on Human Decision Making and Productivity." Indoor Air Conference, Austin, TX, abstract 574.

Satish, U., J. F. William, J. M. Mark, E. Ekaterina, H. Toshifumi, P. S. Douglas, B. C. Lisa, S. Krishnamurthy, and

T. Kaeling 2012. "Is CO2 an Indoor Air Pollutant? Direct Effects of Low-to-Moderate CO2 Concentrations on Human Decision-Making Performance." Environmental Health Perspectives 120: 1671-1677.

Scottish Government. 2006. "Health in Scotland 2006: Annual Report of the Chief Medical Officer." Accessed March 26, 2013. http://www.scotland.gov.uk/Publications/2007/11/15135302/10

Shepherd, D., D. Welch, K. Dirks, and D. McBride. 2013. “Do Quiet Areas Afford Greater Health-Related Quality of Life than Noisy Areas?" International Journal of Environmental Research and Public Health 10 (4): 1284-1303.

Shields, B. 2003. “Learning's Sound Barrier." by Nina Morgan. Newsline 26: 10-11.

Singh, J. 1996. "Review: Health, Comfort and Productivity in the Indoor Environment." Indoor Built Environment Journal 5 (1): 22-33.

Singh, A., Matt Syal, Sue C. Grady, and Sinem Korkmaz. 2010. "Effects of Green Buildings on Employee Health and Productivity." American Journal of Public Health 100 (9): 1665-1668.

Steemers, K., and S. Manchanda. 2010. “Energy Efficient Design and Occupant Well-being: Case Studies in the UK and India." Building and Environment 45: 270-278.

Stools, D. 1992. "Establishing and Maintaining Healthy Environments: Toward a Social Ecology of Health Promotion." American Psychologist 47 (1): 6-22.

Strelitz, Z. 2008. Buildings that Feel Good. London: RIBA Publishing.

Thompson, B., and D. Jonas. 2008. “Workplace Design and Productivity: Are they Inextricably Interlinked?”

Property in the Economy Report. Royal Institution of Chartered Surveyors (RICS), London, pp. 4-41.

UK Centre for Mental Health. 2011. "Managing Presenteeism." Report,

http://www.centreformentalhealth.org.uk Ulrich, R. S. 1984. "View through a Window may Influence Recovery from Surgery." Science 224: 420-421.

Ulrich, R. S. 1991. "Effects of Interior Design on Wellness: Theory and Recent Scientific Research." Journal of Health Care Interior Design 1 (3): 97-109.

USDAW (Union of Shop, Distributive and Allied Workers). 2006. “Work Section.” The Guardian, 8 July.

Accessed August 30, 2012. http://www.guardian.co.uk/theguardian/2006/jul/08/work

US Green Building Council. 2003. "Making the Business Case for High Performance Green Buildings." US

Green Building Council, Washington, DC. Accessed March 26, 2013. https://www.usgbc.org/Docs/

Member_Resource_Docs/makingthebusinesscase.pdf 
Veitch, J. A., and A. D. Galasiu. 2012. "The Physiological and Psychological Effects of Windows, Daylight, and View at Home." Review and Research Agenda No. IRC-RR-325. NRC Institute for Research in Construction, Ottawa, Canada.

Vischer, J. C. 2008. "Towards an Environmental Psychology of Workspace: How People are Affected by Environments for Work." Architectural Science Review 51 (2): 97-108.

van der Voordt, D. J. M. 2003. Costs and Benefits of Innovative Workplace Design, Centre for People and Buildings, Delft \& Centrum Facility Management, Naarden: Summary \& Book Review. ISBN 90807720-3-8.

Wargocki, P., O. Seppanen, J. Andersson, A. Boerstra, D. J. Clements-Croome, K. Fitzner, and S. O. Hanssen. 2006. "Indoor Climate and Productivity in Offices. REHVA Guidebook 6." Federation of European Heating, Ventilation and Air-conditioning Associations (REHVA), Brussels, Belgium.

Warr, P. 1998a. "What is our Current Understanding of the Relationships Between Well-being and Work." Journal of Occupational Psychology 63: 193-210.

Warr, P. 1998b. "Well-being and the Workplace." In Foundations of Hedonic Psychology: Scientific Perspectives on Enjoyment and Suffering, edited by D. Kahneman, X. El Diener, and N. Schwarz, 392412. New York: Russell-Sage.

Weiss, M. L. 1997. "Division of Behaviour and Cognitive Science." PhD diss., Rochester University, New York, NY, USA.

WGBC (World Green Building Council). 2013. "Report The Business Case for Green Building." http:// www.worldgbc.org/activities/business-case/

Wheeler, G., and A. Almeida. 2006. "These Four Walls: The Real British Office." Chap. 22 in Creating the Productive Workplace, edited by D. Clements-Croome, 357-377. London: Routledge.

Williams, B. 2006. "Building Performance: The Value Management Approach." Chap. 27 in Creating the Productive Workplace, edited by D. J. Clements-Croome (pp. 434-457). London: Routledge.

Wilson, G. 2010. "Infomania Experiment for Hewlett Packard." www.drglennwilson.com/Infomania_ experiment_for_HP.docInfo

WHO (World Health Organisation). 1993. "Indoor Air Pollutants: Exposure and Health Effects." WHO Regional Office for Europe, European Series 91, kk Copenhagen.

Wyon, D., and P. Wargocki. 2013. "How Indoor Environment Affects Performance." ASHRAE Journal 55 (3): 46-52. 